\title{
Estimated glomerular filtration rate in patients with type 2 diabetes mellitus
}

\author{
Paula Caitano Fontela ${ }^{1}$, Eliane Rosel Winkelmann ${ }^{2}$, Joice Nedel $0 T^{3}{ }^{3}$, Douglas Prestes Uggeri ${ }^{4}$ \\ ${ }^{1}$ Physiotherapy undergraduate student, Regional University of the Northwest of Rio Grande dos Sul State (Unijuñ), PIBIC/CNPq grant recipient, ljuí, RS, Brazil \\ ${ }^{2} \mathrm{PhD}$ - lecturer at the Regional University of the Northwest of Rio Grande do Sul State (Unijuí), ljuí, RS, Brazil \\ 3Pharmaceutical biochemist - responsible for the Clinical Analysis Laboratory at UNIJUÍ (UNILAB), ljuí, RS, Brazi \\ 4Physician specialized in nephrology - physician at the ljuí Charity Hospital (HCl), ljuí, RS, Brazil
}

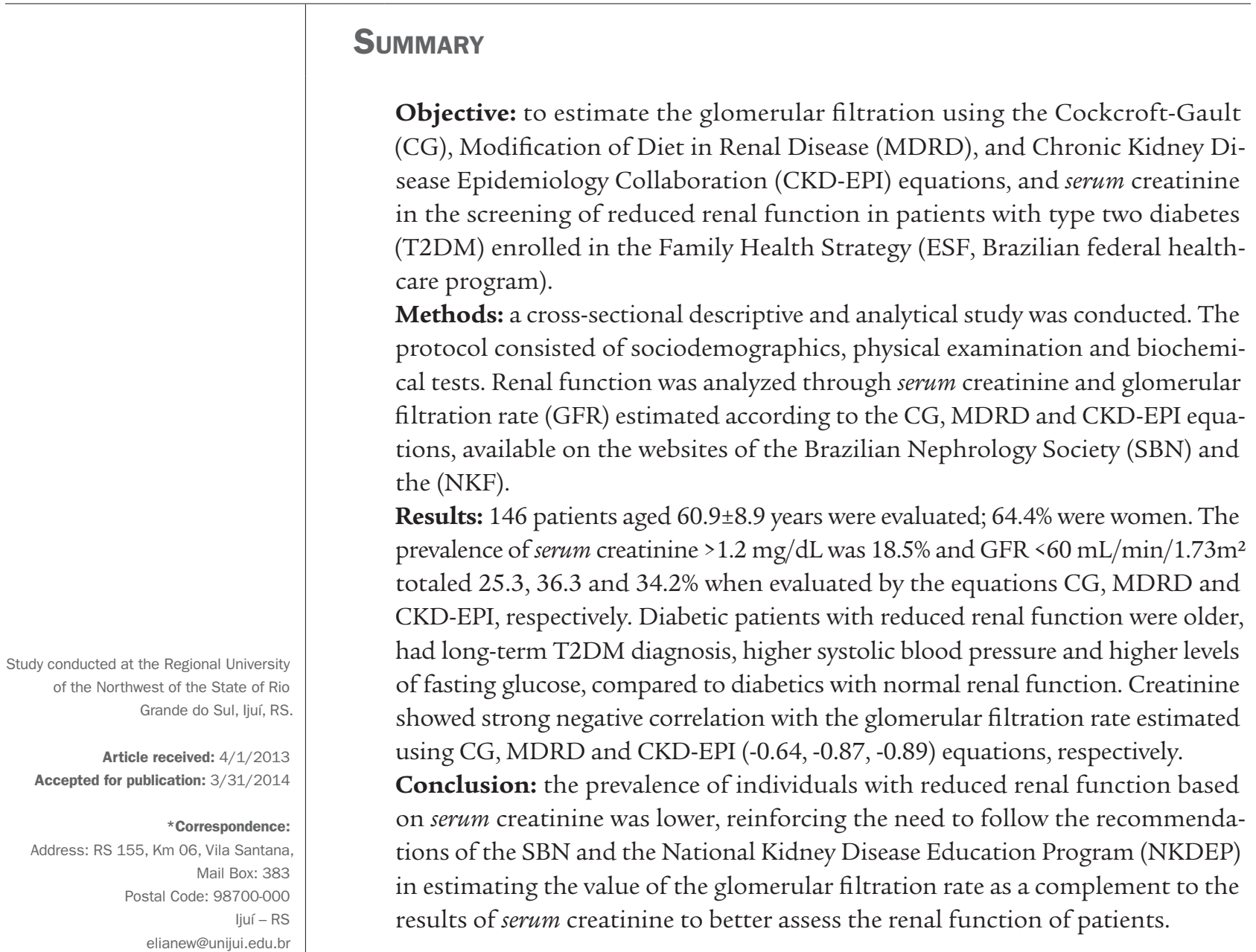

http://dx.doi.org/10.1590/1806-9282.60.06.010

Conflict of interest: none

Keywords: type 2 diabetes mellitus, kidney function tests, kidney failure, chronic, public health.

\section{INTRODUCTION}

Assessment of renal function in individuals with diabetes mellitus (DM) is extremely important since diabetic nephropathy $(\mathrm{DN})$ constitutes a major cause of chronic kidney disease in the world, which makes DM the most frequent cause of end-stage renal disease. ${ }^{1,2}$ Approximately $40 \%$ of all diabetic patients develop $\mathrm{DN},{ }^{3}$ which is the most common diagnosis among individuals in renal replacement programs, accounting for up to $44 \%$ of cases. ${ }^{4}$
In Brazil, in 2010, $27.5 \%$ of patients on dialysis had DN, and it is likely that in the coming years a significant increase in the number of diabetic patients undergoing dialysis therapy occurs. ${ }^{5}$

Early identification and appropriate management of chronic kidney disease (CKD) are important measures to slow its progression. In clinical practice, measurement of plasma creatinine has been the method most often used 
to assess renal function. However, it has been demonstrated that "apparently normal" serum creatinine levels may be accompanied by loss of renal function, making this a relatively late parameter for lesion detection. ${ }^{6}$ Although the measurement of the calculated creatinine clearance is considered the reference standard for determining the glomerular filtration, its methods are laborious, expensive and require specialized equipment and personnel, making them impractical in daily practice. ${ }^{7}$ Therefore, some formulas to estimate GFR were developed, and the most employed and analyzed equations are Cockcroft and Gault (CG) ${ }^{8}$ Modification of Diet in Renal Disease (MDRD) ${ }^{9}$ and Chronic Kidney Disease Epidemiology Collaboration (CKD-EPI). ${ }^{10}$

The SBN and the NKDEP have recommended informing the amount of estimated glomerular filtration rate as a complement to results of serum creatinine. ${ }^{11}$ Currently, the American Diabetes Association (ADA) recommends annual screening of $\mathrm{DN}$ with evaluation of the urinary excretion of albumin and GFR estimated using equations that include serum creatinine, ${ }^{12}$ while the NKF recommends that the MDRD equation should be used to estimate GFR. ${ }^{13}$

That said, the present study aimed at estimating the filtration rate by using the CG, MDRD and CKD-EPI equations, and serum creatinine as methods for screening reduced renal function in patients with T2DM enrolled in the ESF program.

\section{Methods}

A cross-sectional descriptive and analytical study was conducted, including a sample of patients with type 2 diabetes mellitus, enrolled in the Family Health Strategy and living in the urban area of the municipality of Ijuí, state of Rio Grande do Sul (Brazil). The exclusion criteria were: individuals older than 75 years, difficulty understanding the proposed procedures, bedridden individuals, or impairments during ambulation.

The sample size was calculated according to population data from 2009, in which the city of Ijuí had a total of 819 diabetics enrolled in nine ESF centers, in urban areas. The StatCalc application of Epi Info 3.5.3 software was used; considering a prevalence of nonspecific outcome of $50 \%, 95 \%$ confidence interval, and $5 \%$ alpha-type error, we obtained a sample size of 269 patients, including $5 \%$ for possible losses, leaving a sample size of 283 patients. Later, we contacted the head nurse of each ESF center to conduct a meeting with the community health workers to present the project and decide which patients would be evaluated, which was done randomly by sortition.
The invitation to participate in the study was done to patients during home visits in the company of community health workers, whenever possible. On these occasions, the research project was explained to the patients, and the clinical and laboratory evaluations of the patients who agreed to participate were scheduled. The evaluations were performed, in the Physiotherapy Clinic at the Regional University of the Northwest of the State of Rio Grande do Sul (Unijuí), and the clinical analyses laboratory of Unijuí (Unilab), respectively, being performed by health professionals properly trained to standardize the assessments.

To analyze the social habits and health status of patients with T2DM a structured interview that sought to identify cardiovascular risk factors was performed. Every patient who claimed to be a smoker at the time of the evaluation, regardless of the number of cigarettes, was classified as a smoker; likewise, those who reported drinking alcohol during the study period in any quantity and frequency were classified as drinkers. Excessive salt intake and stress were considered according to the patient's own perception. Individuals who reported exercising at least three times per week, each session lasting 30 minutes, were classified as physically active. The others were considered sedentary.

At the same time, systolic (SBP) and diastolic blood pressure (DBP) were measured in millimeters of mercury $(\mathrm{mmHg}){ }_{1}^{14}$ using aneroid sphygmomanometer with the patient seated; blood pressure measurement was standardized in the right upper limb. The evaluation of anthropometric data was also performed. Weight (in kilograms) was measured using a digital scale $\left(\right.$ Toledo $\left.^{\circledR}\right)$, and height (in meters) using a stadiometer (Toledo ${ }^{\circledR}$ ), according to recommended techniques. ${ }^{15}$ The ideal body weight for each patient was calculated using the CG and Lorenz' formulas, which estimate the ideal weight in terms of the individual's height in centimeters. The Body Mass Index (BMI) was calculated using the ratio of body weight and height squared $\left(\mathrm{Kg} / \mathrm{m}^{2}\right)$ and classified according to the criteria used by the World Health Organization (WHO). ${ }^{16}$ Waist circumference (WC) was measured at the midpoint between the last rib and the iliac crest, whereas hip circumference (HC) was measured over the iliac crest, using standard measuring tape, flexible and non-extensible, accurate to $1 \mathrm{~mm}^{17}$

Date and time of lab test appointments were scheduled at the end of the interview and clinical evaluation. Patients were personally informed about the procedures for sample collection, and instructed to fast for at least eight 
hours before blood collection, in addition to receiving written instructions and containers for collection of first morning urine.

Renal function was assessed based on the result of serum creatinine, obtained from biochemical test, and GFR estimated using CG, MDRD and CKI-EPI equations, calculated using the formulas provided in the SBN and NKF websites. Values above $1.2 \mathrm{mg} / \mathrm{dL}$ for serum creatinine $\mathrm{e}^{18}$ and below $60 \mathrm{~mL} / \mathrm{min} / 1.73 \mathrm{~m}^{2}$ for GFR estimated by CG, MDRD and CKI-EPI, ${ }^{19,20}$ were regarded as impaired renal function, since aglomerular filtration rate below $60 \mathrm{~mL} /$ $\mathrm{min} / 1.73 \mathrm{~m}^{2}$ represents a decrease of approximately $50 \%$ in normal renal function, which, below this level, increases the prevalence of complications of CKD. ${ }^{21}$

For data processing, we used the statistical Package for Social Science - SPSS software (18.0 version, Chicago, IL, USA). In the statistical analysis, all variables were tested for normality using the test Kolmogorov-Smirnov (K-S). Qualitative variables are presented as frequencies and percentages, and quantitative variables as mean and standard deviation (mean $\pm \mathrm{SD}$ ). We used Mann-Whitney test for comparison of two independent groups with non-normal distribution and the Student's $t$ test for variables with normal distribution in order to verify variable differences per gender, and between individuals with normal and reduced renal function. The Spearman correlation coefficient was used to evaluate the correlation between clinical/biochemical parameters and GFR estimated using CG, MDRD and CKD-EPI equations. We considered statistically significant $\mathrm{p}<0.05$. All tests were applied with a confidence interval (CI) of $95 \%$.

The research project was approved by the Research Ethics Committee (CEP) at Unijuí, after consolidated opinion $\mathrm{n}^{\circ} 91 / 2010$.

\section{RESULTS}

283 patients with T2DM who met the study's criteria were selected for a home visit and invitation to participate, based on information collected by ESF health workers or gathered from medical records kept at nine ESF centers in the urban area of the municipality of Ijuí, state of Rio Grande do Sul. Out of this total, 64 patients were excluded from the study because they either did not attend the visit, did not accept the invitation to join the study, did not identify the address provided, or did not sign the Free and Informed Consent form. Of the 219 diabetic participants, we excluded 73 (33.33\%) due to insufficient data to assess renal function, since they did not perform biochemical tests for serum creatinine; this led to a total sample of 146 patients with T2DM in the present study.
Patients had a mean age of $60.9 \pm 8.9$ years; $64.4 \%$ (94/146) were female. Time of T2DM diagnosis, body mass, height, systolic blood pressure, serum creatinine and GFR by CG, MDRD and CKD-EPI equations were greater on average among men, while among women body mass index, waist circumference, hip circumference, serum blood glucose, total cholesterol and triglycerides were higher. Waist circumference, time of type 2 diabetes' diagnosis, diastolic blood pressure, fasting blood glucose, total cholesterol and GFR according to the CG equation were variables that did not differ statistically ( $p>0.05)$ (Table 1).

TABLE 1 Clinical profile of patients with type 2 diabetes mellitus

\begin{tabular}{|c|c|c|c|}
\hline Variables & $F(n=94)$ & $M(n=52)$ & $\mathbf{p}$ \\
\hline & $\mathrm{M} \pm \mathrm{DP}$ & $\mathrm{M} \pm \mathrm{DP}$ & \\
\hline Age (years) & $59.7 \pm 9.2$ & $63.3 \pm 8.1$ & $0.04 * £$ \\
\hline Body mass $(\mathrm{Kg})$ & $78.3 \pm 16.1$ & $81.9 \pm 12.2$ & $0.04 * £$ \\
\hline Height $(\mathrm{cm})$ & $155.0 \pm 5.7$ & $169.2 \pm 6.3$ & $0.000 * * £$ \\
\hline $\operatorname{BMI}\left(\mathrm{Kg} / \mathrm{m}^{2}\right)$ & $32.5 \pm 6.3$ & $28.7 \pm 4.1$ & $0.000 * * £$ \\
\hline$W C(\mathrm{~cm})$ & $105.8 \pm 14.5$ & $103.8 \pm 10.2$ & $0.18 £$ \\
\hline $\mathrm{HC}(\mathrm{cm})$ & $108.9 \pm 13.3$ & $101.9 \pm 10.2$ & $0.001 * * £$ \\
\hline TD-T2DM (years) & $6.9 \pm 7.2$ & $8.2 \pm 7.4$ & $0.21 £$ \\
\hline $\mathrm{SBP}(\mathrm{mmHg})$ & $132.0 \pm 16.6$ & $138.9 \pm 15.3$ & $0.005^{* * £}$ \\
\hline $\mathrm{DBP}(\mathrm{mmHg})$ & $82.7 \pm 10.8$ & $82.5 \pm 14.8$ & $0.45 £$ \\
\hline Fasting blood glucose (mg/dL) & $127.1 \pm 53.8$ & $122.2 \pm 48.2$ & $0.78 £$ \\
\hline Total cholesterol (mg/dL) & $179.6 \pm 44.1$ & $169.9 \pm 52.2$ & $0.23 ?$ \\
\hline Triglycerides (mg/dL) & $196.9 \pm 105.6$ & $165.2 \pm 95.2$ & $0.04 * £$ \\
\hline Serum creatinine $(\mathrm{mg} / \mathrm{dL})$ & $1.0 \pm 0.29$ & $1.1 \pm 0.35$ & $0.03 * £$ \\
\hline $\mathrm{CG}\left(\mathrm{mL} / \mathrm{min} / 1.73 \mathrm{~m}^{2}\right)$ & $80.6 \pm 32.0$ & $85.7 \pm 30.5$ & $0.16 £$ \\
\hline $\operatorname{MDRD}\left(\mathrm{mL} / \mathrm{min} / 1.73 \mathrm{~m}^{2}\right)$ & $66.2 \pm 22.1$ & $79.3 \pm 26.4$ & $0.001 * * £$ \\
\hline CKD-EPI $\left(\mathrm{mL} / \mathrm{min} / 1.73 \mathrm{~m}^{2}\right)$ & $66.5 \pm 20.4$ & $74.5 \pm 20.5$ & $0.01 * * £$ \\
\hline
\end{tabular}

*: $\mathrm{p}<0.05$; **: $\mathrm{p}<0.01$; F: female; M: male; M $\pm D P$ : mean \pm standard deviation; $£:$ Mann-Whitney test; ?: Student's t test; $\mathrm{kg}$ : kilogram; $\mathrm{cm}$ : centimeters; $\mathrm{Kg} / \mathrm{m}^{2}:$ kilograms per square meter; WC: waist circumference; HC: hip circumference; TD-T2DM: time of diagnosis of T2DM; SBP: systolic blood pressure; $\mathrm{mmHg}$ : millimeters of mercury; DBP: diastolic blood pressure; mg: milligrams; $\mathrm{dL}$ : deciliter; CG: Cockcroft-Gault; $\mathrm{mL}$ : milliliter; min: minute; $\mathrm{m}^{2}$ : square me ter; MDRD: Modification of Diet in Renal Disease; CKD-EPI: Chronic Kidney Disease Epidemiology Collaboration.

With regard to the social habits and medical history of the patients with T2DM, we observed that most diabetics were older $(58.2 \%)$, considered overweight $(35 \%)$ or class I obese (30.1\%), referred the absence of hypersodic diet (82.9\%) and had high blood pressure (73.3\%) associated with T2DM. The prevalence of smoking and drinking habits in the population studied was $15.8 \%$ and $6.8 \%$, respectively. Almost $3 / 4$ of the sample (73.1\%) said that they did not exercise regularly.

The assessment of renal function, according to serum creatinine and GFR calculated using GC MDRD and CKD-EPI equations, shows that the prevalence of serum 
creatinine above $1.2 \mathrm{mg} / \mathrm{dL}$ was $18.5 \%$. In the case of GFR below $60 \mathrm{~mL} / \mathrm{min} / 1.73 \mathrm{~m}^{2}$, one can observe a decrease in renal function of $25.3,36.3$ and $34.2 \%$ when assessed by CG, MDRD and CKD-EPI equations, respectively. This classification was used to categorize individuals according to demographic, anthropometric, clinical and laboratory characteristics of T2DM patients (Table 2).

According to the screening methods for reduced renal function in patients with T2DM used in this study, patients with impaired renal function are older, have diag- nosed their condition for longer times, and show higher values for SBP and fasting blood glucose (Table 2).

In Table 3 , the correlations between clinical and biochemical parameters and GFR estimated based on the equations were negative for serum creatinine, age and time of diagnosis of T2DM, and positive between body/mass BMI and GFR estimated using CG equation. In spite of having achieved statistical significance, we point out that the correlations found between GFR, according to the equations, and the clinical pa-

TABLE 2 Evaluation of demographic, anthropometric, clinical and laboratory characteristics according to the criteria adopted for assessment of renal function in T2DM

\begin{tabular}{|c|c|c|c|c|c|c|c|c|}
\hline Variables & $\begin{array}{l}\text { Serum } \\
\text { creatinine }\end{array}$ & & CG & & MDRD & & CKD-EPI & \\
\hline & $\begin{array}{l}\text { Normal } \\
(n=119)\end{array}$ & $\begin{array}{l}\text { Impaired } \\
(n=27)\end{array}$ & $\begin{array}{l}\text { Normal } \\
(n=109)\end{array}$ & $\begin{array}{l}\text { Impaired } \\
(n=37)\end{array}$ & $\begin{array}{l}\text { Normal } \\
(n=93)\end{array}$ & $\begin{array}{l}\text { Impaired } \\
(n=53)\end{array}$ & $\begin{array}{l}\text { Normal } \\
(n=96)\end{array}$ & $\begin{array}{l}\text { Impaired } \\
(n=50)\end{array}$ \\
\hline Gender ( $\left.F^{*} \cdot M\right)$ & $83 * 36$ & $11 * 16$ & $68 * 41$ & $26 * 11$ & $53 * 40$ & $41^{*} 12^{*}$ & $57 * 39$ & $37^{*} 13$ \\
\hline Age (years) & $60.4 \pm 9.3$ & $63.8 \pm 6.7^{*}$ & $58.9 \pm 8.4$ & $67.1 \pm 7.8 * *$ & $59.9 \pm 9.3$ & $62.9 \pm 8.1^{*}$ & $59.2 \pm 9.4$ & $64.4 \pm 6.9^{* *}$ \\
\hline $\begin{array}{l}\text { TD-T2DM } \\
\text { (years) }\end{array}$ & $6.8 \pm 6.7$ & $9.8 \pm 9.1$ & $6.7 \pm 6.5$ & $9.6 \pm 8.5^{*}$ & $6.4 \pm 6.1$ & $9.0 \pm 8.7^{*}$ & $6.4 \pm 6.0$ & $9.2 \pm 9.0$ \\
\hline $\mathrm{BMI}\left(\mathrm{Kg} / \mathrm{m}^{2}\right)$ & $31.3 \pm 6.0$ & $30.3 \pm 5.0$ & $32.3 \pm 5.7$ & $27.7 \pm 4.8 * *$ & $30.6 \pm 5.3$ & $32.0 \pm 6.8$ & $30.7 \pm 5.5$ & $32.0 \pm 6.4$ \\
\hline $\mathrm{WC}(\mathrm{cm})$ & $104.8 \pm 13.3$ & $106.4 \pm 12.7$ & $107.5 \pm 11.8$ & $98.1 \pm 14.3 * *$ & $104.5 \pm 10.9$ & $106.3 \pm 16.3$ & $104.3 \pm 11.7$ & $106.7 \pm 15.5$ \\
\hline $\mathrm{HC}(\mathrm{cm})$ & $106.8 \pm 13.2$ & $104.9 \pm 10.2$ & $108.8 \pm 12.0$ & $99.2 \pm 12.2^{* *}$ & $105.9 \pm 12.7$ & $107.3 \pm 12.8$ & $105.8 \pm 13.2$ & $107.6 \pm 11.7$ \\
\hline $\mathrm{SBP}(\mathrm{mmHg})$ & $132.7 \pm 15.2$ & $142.2 \pm 19.5^{*}$ & $134.1 \pm 16.3$ & $135.6 \pm 17.3$ & $133.0 \pm 16.1$ & $137.0 \pm 17.1$ & $132.6 \pm 15.9$ & $138.0 \pm 17.0 *$ \\
\hline $\mathrm{DBP}(\mathrm{mmHg})$ & $81.7 \pm 11.2$ & $86.7 \pm 15.9$ & $82.8 \pm 12.8$ & $82.4 \pm 10.7$ & $82.1 \pm 13.0$ & $83.7 \pm 11.1$ & $81.9 \pm 12.8$ & $84.1 \pm 11.2$ \\
\hline $\mathrm{TC}(\mathrm{mg} / \mathrm{dL})$ & $175.6 \pm 45.5$ & $178.4 \pm 55.1$ & $178.7 \pm 47.1$ & $168.7 \pm 47.3$ & $178.1 \pm 45.7$ & $172.8 \pm 49.9$ & $178.3 \pm 46.6$ & $172.1 \pm 48.5$ \\
\hline Trig. (mg/dL) & $186.2 \pm 104.9$ & $183.0 \pm 94.4$ & $188.1 \pm 98.3$ & $178.2 \pm 116.1$ & $182.8 \pm 95.7$ & $190.5 \pm 115.0$ & $185.1 \pm 105.5$ & $186.5 \pm 98.4$ \\
\hline $\mathrm{FG}(\mathrm{mg} / \mathrm{dL})$ & $120.0 \pm 45.0$ & $148.7 \pm 71.3$ & $124.9 \pm 48.3$ & $126.4 \pm 61.6$ & $121.2 \pm 43.8$ & $132.5 \pm 63.3$ & $123.7 \pm 46.5$ & $128.5 \pm 61.1$ \\
\hline
\end{tabular}

Mann-Whitney test. *: $p<0,05$; **: p<0,01; F: female; M: male; CG: Cockcroft-Gault; MDRD: Modification of Diet in Renal Disease; CKD-EPI: Chronic Kidney Disease Epidemiology Collaboration; TD-T2DM: Time of diagnosis of T2DM; BMI: body mass index; $\mathrm{Kg} / \mathrm{m}^{2}$ : kilograms per square meter; WC: waist circumference; cm: centimeters; HC: hip circumference; SBP: systolic blood pressure; mmHg: millimeters of mercury; DBP: diastolic blood pressure; TC: total cholesterol; mg: milligrams; dL: deciliter; Trig.: triglycerides; FG: fasting blood glucose.

TABLE 3 Correlation coefficients between clinical/biochemical parameters and glomerular filtration rate, estimated by the CG, MDRD, CKD-EPI equations for patients with T2DM enrolled in the ESF program

\begin{tabular}{l|l|l|l} 
& GFR CG & GFR MDRD & GFR CKD-EPI \\
\hline Age (years) & $\mathbf{r}$ & $\mathbf{r}$ & $\mathbf{r}$ \\
\hline TD-T2DM (years) & $-0.57^{* * *}$ & $-0.20^{*}$ & $-0.30^{* * *}$ \\
\hline Body mass $(\mathrm{Kg})$ & $-0.29^{* * *}$ & $-0.18^{*}$ & $-0.21^{* *}$ \\
\hline Body mass index $\left(\mathrm{kg} / \mathrm{m}^{2}\right)$ & $0.44^{* *}$ & 0.16 & -0.02 \\
\hline Fasting blood glucose $(\mathrm{mg} / \mathrm{dL})$ & $0.38^{* * *}$ & -0.07 & -0.08 \\
\hline Total cholesterol $(\mathrm{mg} / \mathrm{dL})$ & 0.07 & -0.04 & -0.02 \\
\hline Triglycerides $(\mathrm{mg} / \mathrm{dL})$ & -0.01 & -0.02 & -0.00 \\
\hline Serum creatinine $(\mathrm{mg} / \mathrm{dL})$ & -0.05 & -0.14 & -0.11 \\
\hline Sp & $-0.64^{* *}$ & $-0.87^{* * *}$ & $-0.89^{* * *}$
\end{tabular}

Spearman Correlation Test; *: $\mathrm{p}=0.05 ; * *$ : $<<0.01 ; * * *: p<0.001 ;$; CG: Cockcroft-Gault; MDRD: Modification of Diet in Renal Disease; CKD-EPI: Chronic Kidney Disease Epidemiology Collaboration; TD-T2DM: Time of diagnosis of T2DM; BMI: body mass index; $\mathrm{Kg} / \mathrm{m} 2$ : kilograms per square meter; WC: waist circumference; $\mathrm{cm}$ : centimeters; HC: hip circumference; SBP: systolic blood pressure; mmHg: millimeters of mercury; DBP: diastolic blood pressure; TC: total cholesterol; mg: milligrams; dL: deciliter; Trig.: triglycerides; FG: fasting blood glucose. 
rameters were not considered strong, unlike that observed with serum creatinine.

\section{Discussion}

From the results of this study, we highlight the lower prevalence of impaired renal function observed through serum creatinine. This supports the literature findings that indicate that serum creatinine alone is not a sensitive method to assess renal function in asymptomatic CKD patients. $^{22}$

Following the recommendations of the SBN and the NKDEP, the value of GFR is estimated as a complement to the results of serum creatinine to better assess a patient's renal function. In this study, the prevalence of impaired renal function estimated by GFR calculation, using the CG, MDRD and CKD-EPI equations, was homogeneous (25.3, 36.3 and $34.2 \%)$. There is, however, greater similarity between the results of the MDRD and CKD-EPI equations, and a more marked difference (11\%) compared to the CG equation, which resulted in prevalence almost twice greater than the change in renal function estimated through serum creatinine.

The literature reports that both equations show excellent correlation with the calculated GFR. ${ }^{21}$ However, studies indicate that the MDRD equation proves more effective in detecting changes in patients with early renal disease, ${ }^{23}$ as seen in the present study, where the prevalence of decreased renal function was greater in diabetic patients assessed by MDRD.

In this context, we draw attention to the fact that the formulas most commonly used and known to estimate GFR were validated in studies with target populations, thus presenting singularities. The CG formula was the first of these equations to gain acceptance, estimating creatinine clearance. When originally described, the CG equation was based on urinary creatinine excretion of hospitalized Caucasian men, aged 18-92 years and with normal renal function. The calculation was not standardized for a body surface area of $1.73 \mathrm{~m}^{2}$ and a correction was necessary for women. ${ }^{8}$ It systematically overestimates the GFR, because tubular creatinine secretion and the increase in weight due to obesity or fluid overload are not taken into consideration. ${ }^{24}$

The MDRD equation to estimate GFR was originally developed based on data from a study entitled Modification of Diet in Renal Disease, which included CKD patients and not healthy individuals. The gold standard used to develop the MDRD equation was that of $125 \mathrm{I}$-iothalamate clearence, which estimates GFR in $\mathrm{mL} / \mathrm{min} / 1.73 \mathrm{~m}^{2}$, and not creatinine clearance. ${ }^{9}$ In its original version, the MDRD equa- tion requires the determination of serum albumin and urea nitrogen. Currently, the abbreviated MDRD formula with four variables has been recommended, because its performance is as good as the initial equation's. ${ }^{25}$ GFR as calculated using MDRD and the actual GFR are very close to each other for results below $60 \mathrm{~mL} / \mathrm{min} / 1.73 \mathrm{~m}^{2}$, while the GFR exceeds the estimated rate by a small difference when the result is greater than $60 \mathrm{~mL} / \mathrm{min} / 1.73 \mathrm{~m}^{2} .{ }^{26}$

The Chronic Kidney Disease Epidemiology Collaboration (CKD-EPI) group has recently developed, based on a cohort study that included individuals with and without $\mathrm{CKD}$, a new equation which is a variation of the MDRD formula. ${ }^{10}$ The equation, called CKD-EPI, uses the same four variables adopted by the MDRD equation, but comparatively has better performance and risk prediction.

Using the results of this practical study to calculate GFR estimated by MDRD, which is considered more effective, ${ }^{23} 36.3 \%$ of the patients were found to present levels below $60 \mathrm{~mL} / \mathrm{min} / 1.73 \mathrm{~m}^{2}$. This represents an approximate decrease of $50 \%$ in normal kidney function. ${ }^{21}$ Of these patients $77.4 \%$ (41/53) were women. According to the literature, levels of glomerular filtration rate below that show increased prevalence of complications of CKD. The minimum value found in this study was 20, 21 and $25.40 \mathrm{~mL} / \mathrm{min} / 1.73 \mathrm{~m}^{2}$, estimated using the CKD-EPI, MDRD and CG equations, respectively. When the GFR reaches very low values, less than $15 \mathrm{~mL} / \mathrm{min} / 1.73 \mathrm{~m}^{2}$, the so-called functional renal failure occurs, that is, the most advanced stage of progressive functional loss observed in $\mathrm{CKD}$, which was never observed in the present study.

The mean estimated GFR according to CG equation for men and women in this study $(85.7 \pm 30.5$ and $80.6 \pm 32.0 \mathrm{~mL} / \mathrm{min}$, respectively) had similar results to those found in the study by Guimarães et al. ${ }^{27}$ that also assessed a population of diabetic patients, finding the estimated creatinine clearence at $71.67 \pm 30.85 \mathrm{~mL} /$ $\mathrm{min} / 1.73 \mathrm{~m}^{2}$, using the CG calculation. The latter also compared the GFR results determined by radioisotope methods and equivalent levels for GFR estimated using creatinine clearence. They came to the conclusion that the creatinine clearence underestimates the clearence of DTPA-Tc $99 \mathrm{~m}$, particularly when the values for GFR are higher. Nevertheless, they claim that the CG formula is useful when GFR is below $100 \mathrm{~mL} / \mathrm{min} / 1.73 \mathrm{~m}^{2}$, phase in which it is more accurate since the repeated use of a radioisotope method becomes impractical. ${ }^{27}$

It is possible, therefore, to observe that the use of formulas to determine GFR has been widely adopted and correlated well with radioisotope methods to measure glomerular filtration, especially when it is decreased 
$\left(<60 \mathrm{~mL} / \mathrm{min} / 1.73 \mathrm{~m}^{2}\right) .{ }^{9}$ Using these equations to estimate GFR has lower cost and greater convenience in clinical practice, ${ }^{8,9}$ facilitating early screening and diagnosis of $\mathrm{CKD}$ in diabetics in primary care.

The various formulas were created to calculate the GFR more accurately, and they include not only the serum concentration of creatinine, but also correction factors, which allow for a greater individualization of the results, increasing the test's sensitivity aiming at detecting deficits in renal function..$^{28}$ But we cannot forget that, in elderly patients, glomerular filtration may decrease as part of the body's aging process, and it can be difficult to differentiate the age-related decrease in glomerular filtration from that seen in renal dysfunction in the elderly. Therefore, for purposes of stratification and intervention, the diagnosis of renal dysfunction should not be solely based on the estimate of GFR, but also the presence of other markers of kidney disease. ${ }^{29}$

The present study did not use any gold standard marker (insulin or iothalamate clearance) for comparison due to high cost, extended time for the procedure, and difficult access for patients followed in primary care. Given this bias, serum creatinine is the most widely used method because of its low cost and accessibility to users of public services. Another limitation of the study is the lack of association between the drugs taken by the patients and their GFR, since the drug therapy may interfere with the glomerular filtration rate and lipid profile.

But more than the comparison of formulas, we stress the importance of early diagnosis to improve the health and enhance the quality of life of diabetic patients. From routine screening and the application of calculations to estimate the GFR, it is possible to determine the renal function in these individuals earlier, and thus try to reduce the prevalence and incidence of renal failure through the adoption of intervention measures. This is most relevant since, currently, CKD is considered a global public health problem, DM being the most common cause of $\mathrm{CKD}$ in the world and the second most common etiology among dialysis patients in Brazil.

Also important forms of intervention are actions guided to change the patients' lifestyle, which is crucial to halt the progression of CKD. Dieting, exercising, controlling blood pressure and blood glucose, controlling dyslipidemia and obesity are all measures more effective than oral hypoglycemic agents.

After analyzing the results, we conclude that the prevalence of individuals with reduced renal function based on serum creatinine was lower, reinforcing the need to follow the recommendations of the SBN and the NKDEP, which is estimating the value of glomerular filtration as a complement to the results of serum creatinine to better assess the patients' renal function. Diabetic patients with reduced renal function were older, had their T2DM diagnosis for a longer time, higher systolic blood pressure and higher levels of fasting blood glucose, compared to diabetics with normal renal function.

\section{Acknowledgements}

The support was provided by the Rio Grande do Sul State Research Foundation (Fapergs), the National Council of Scientific and Technological Development (CNPq) and the Regional University of the Northwest of the State of Rio Grande do Sul (Unijuí) through the granting of scientific initiation scholarships.

\section{Resumo}

Estimativa da taxa de filtração glomerular em pacientes com diabetes mellitus tipo 2 .

Objetivo: estimar a taxa de filtração glomerular por meio das equações Cockcroft e Gault (CG), Modification of Diet in Renal Disease (MDRD), Chronic Kidney Disease Epidemiology Collaboration (CKD-EPI) e da creatinina sérica na triagem da função renal reduzida em pacientes com diabetes mellitus tipo 2 (DM2), adscritos em estratégia de saúde da família (ESF).

Métodos: foi realizado um estudo transversal, descritivo e analítico. O protocolo foi constituído de dados sociodemográficos, exame físico e dosagens bioquímicas. A função renal foi analisada pela creatinina sérica e pela taxa de filtração glomerular (TFG) estimada segundo as equações CG, MDRD e CKD-EPI, disponibilizadas nos websites da Sociedade Brasileira de Nefrologia (SBN) e da National Kidney Foundation (NKF).

Resultados: foram avaliados 146 pacientes com média de idade de 60,9 98,9 anos; $64,4 \%$ eram mulheres. A prevalência de creatinina sérica $>1,2 \mathrm{mg} / \mathrm{dL}$ foi de $18,5 \%$, e a TFG $<60 \mathrm{~mL} / \mathrm{min} / 1,73 \mathrm{~m}^{2}$ foi de $25,3 \%, 36,3 \%$ e $34,2 \%$ quando avaliadas pelas equações CG, MDRD e CKD-EPI, respectivamente. Os pacientes diabéticos com função renal reduzida eram idosos, apresentavam maior tempo de diagnóstico de DM2, pressão arterial sistólica mais elevada e níveis superiores de glicemia de jejum, quando comparados a diabéticos com função renal normal. A creatinina apresentou correlação negativa e forte com a taxa de filtração glomerular estimada pelas equações CG, MDRD e CKD-EPI $(-0,64 ;-0,87 ;-0,89$, respectivamente). Conclusão: a prevalência de indivíduos com função renal reduzida a partir dos valores de creatinina sérica foi infe- 
rior, reforçando a necessidade de seguir as recomendações da SBN e do National Kidney Disease Education Program (NKDEP) em estimar o valor do ritmo de filtração glomerular como complemento ao resultado da creatinina sérica para melhor avaliar a função renal dos pacientes.

Palavras-chave: diabetes mellitus tipo 2; testes de função renal; falência renal crônica; saúde pública.

\section{References}

1. Atkins RC, Zimmet P. World Kidney Day 2010: diabetic kidney disease-act now or pay later. Am J Kidney Dis. 2010;55:205-8.

2. Zhang QL, Rothenbacher D. Prevalence of chronic kidney disease in population-based studies: systematic review. BMC Public Health. 2008;8:117.

3. Murussi M, Campagnolo N, Beck MO, Gross JL, Silveiro SP. High-normal levels of albuminuria predict the development of micro and macroalbuminuria and increased mortality in Brazilian Type 2 diabetic patients: an 8-year follow-up study. Diabet Med. 2007;24:1136-42.

4. U S Renal Data System, USRDS 2010 Annual Data Report: Atlas of Chronic Kidney Disease and End-Stage Renal Disease in the United States, National Institutes of Health, National Institute of Diabetes and Digestive and Kidney Diseases, Bethesda; 2010

5. Tratamento e acompanhamento do diabetes mellitus. Diretrizes da Sociedade Brasileira de Diabetes. Diagraphic; 2007.

6. Salgado JV, Neves FA, Bastos MG, França AK, Brito DJ, Santos EM, et al. Monitoring renal function: measured and estimated glomerular filtration rates - a review. Braz J Med Biol Res. 2010;43:528-36.

7. Stevens LA, Levey AS. Measured GFR as a confirmatory test for estimated GFR. J Am Soc Nephrol. 2009;20:2305-13.

8. Cockcroft DW, Gault MH. Prediction of creatinine clearance from serum creatinine. Nephron. 1976;04:31 PM-41.

9. Levey AS, Bosch JP, Lewis JB, Greene T, Rogers N, Roth D. A more accurate method to estimate glomerular filtration rate from serum creatinine: a new prediction equation. Ann Intern Med. 1999;130:461-70.

10. Levey AS, Stevens LA, Schmid CH, Zhang YL, Castro AF, Feldman HI, et al A new equation to estimate glomerular filtration rate. Ann Intern Med. 2009;150:604-12.

11. Pereira AB, Nishida SK, Kirstajn GM. Como avaliar o ritmo de filtração glomerular. J Bras Nefrol. 2006;28(Suppl 1):15-8

12. American Diabetes Association. Standards of Medical Care in Diabetes 2010. Diabetes Care. 2010;33:11-61.
13. Levey AS, Coresh J, Balk E, Kausz AT, Levin A, Steffes MW, et al. National Kidney Foundation practice guidelines for chronic kidney disease: evaluation, classification, and stratification. Ann Intern Med. 2003;139:137-47.

14. Sociedade Brasileira de Nefrologia. VI Diretrizes Brasileiras de Hipertensão Arterial. J Bras Nefrol. 2010;32(supl 1):1-64.

15. Kamimura MA, Baxmann A, Sampaio LR, Cuppari L. Avaliação nutricional. In: Cuppari L. Guia de nutrição: nutrição clínica no adulto. São Paulo: Manole; 2005. p.71-108.

16. WHO. World Health Organization. Obesity: preventing and managing the global epidemic. Report of a WHO Consulation. Geneve: WHO; 2005.

17. Heyward VH, Stolarczyc LM. Avaliação da composição corporal aplicada. São Paulo: Manole; 2000. p.73-97.

18. Di Napoli Filho M, Burmeister JE, Miltersteiner DR, Campos BM, Costa MG. Estimativa da função renal pela fórmula de Cockcroft e Gault em pacientes com sobrepeso ou obesidade. J Bras Nefrol. 2008;30:185-91.

19. Magacho EJC, Pereira AC, Mansur HN, Bastos MG. Nomograma para a estimação da taxa de filtração glomerular baseado na Fórmula CKD-EPI. J Bras Nefrol. 2012;34:313-5.

20. National Kidney Foundation - NKF. K/DOQI clinical practice guidelines for chronic kidney disease: evaluation, classification and stratification. Am J Kidney Dis. 2002;39(2 Suppl 1):1-266.

21. Bastos MG, Bregman R, Kirsztajn GM. Doença renal crônica: frequente e grave, mas também prevenível e tratável. Rev Assoc Med Bras. 2010;56:248-53.

22. Shemesh O, Golbetz H, Kriss JP, Meyers BD. Limitations of creatinine as a filtration marker in glomerulopathic patients. Kidney Int. 1985;28:830-8.

23. Sodré FL, Costa JCB, Lima JCC. Avaliação da função e da lesão renal: um desafio laboratorial. J Bras Patol Med Lab. 2007;43:329-37.

24. Bastos MG, Kirsztajn GM. Doença Renal Crônica: importância do diagnóstico precoce, encaminhamento imediato e abordagem interdisciplinar estruturada para melhora do desfecho em pacientes ainda não submetidos à diálise. J Bras Nefrol. 2011;33:93-108.

25. Levey AS, Greene T, Kusek JW, Beck GJ. A simplified equation to predict glomerular filtration rate from serum creatinine. J Am Soc Nephrol. 2000;11:A0828

26. Chronic Kidney Disease Epidemiology Collaboration. Using standardized serum creatinine values in the modification of diet in renal disease study equation for estimating glomerular filtration rate. Ann Intern Med. 2006;145:247-54

27. Guimarães J, Bastos M, Melo M, Carvalheiro M. Nefropatia diabética: taxa de filtração glomerular calculada e estimada. Acta Med Port. 2007;20:145-50

28. Kirsztajn GM. Avaliação do ritmo de filtração glomerular. J Bras Patol Med Lab. 2007;43:257-66.

29. Nogueira CS, Oliveira CRD. Disfunção renal: definição e diagnóstico. São Paulo: SAESP; 2006/2007. Cap. 64, p. 87-125. 